\title{
THE OLD AGE IN POLISH AND AMERICAN SERIES
}

\author{
JOANNA ANIOE \\ Joanna.aniol@gmail.com \\ University of Wrocław, Poland \\ Kaja KoronKiewicz \\ kaja.koronkiewicz@o2.pl \\ University of Wrocław, Poland \\ EDYTA SOKOŁOWSKA \\ edytasokolowska1@gmail.com \\ University of Wrocław, Poland
}

\begin{abstract}
The educational and socialization role of the media is not the latest novelty, however there are niches that have not been developed yet. Realizing the opinion-forming role of the mass media, which may be reflected in social behaviours, the authors of this article will analyse the content of chosen media products. The image of elderly people presented by the most popular Polish and American series will be examined. The research aims to find whether Desperate Housewives and Colours of happiness (original title: Barwy szczęścia) adjust the image of old age to the social-demographic situation, which is constantly changing in the majority of countries. Does the colossus - television promote stereotypes which make age discrimination morally approved - or just the opposite - a well thought out image, shaping the recognition and respect for people in their "third age"?
\end{abstract}

Key words: old age, stereotype, ageism, mass media, series.

Nowadays, significant changes resulting from society ageing can be observed. They are caused by such factors as the growth of life expectancy and the decrease in the frequency of births (Janiszewska-Rain, 2005, p. 593). According to Ewa Kasperek-Golimowska (2008), in developed countries, the elderly (people above the age of 60 ) constitute more than $20 \%$ of the whole society. In Poland, their percentage amounts to $16 \%$ (p. 31). According to the forecasts of [Polish] Central Statistical Office, in 2025 seniors will outnumber the young (the underage) (Straś-Romanowska, 2000, p. 263). What is more, it is predicted that in 2050, in many countries, senior citizens will constitute up to 35\% of the population (Kasperek-Golimowska, 2008, p. 31). In recent years, by reason of demographic changes, the issue of ageing and old age has become subject of interest to various interdisciplinary studies (Bugajska, 2012, p. 13; Błachnio, 2002, p. 14; Pikuła, 2011, p. 101). Nevertheless, Beata Bugajska (2012) claims that there is still too little attention devoted to old age and ways of eliminating problems which seniors have to struggle with, as for a country in which demographic ageing of the society is so clearly observed (p. 8).

Although senior citizens appear in mass media more and more often, the way they are portrayed does not reflect reality. Yet, television serves as a model - it provides viewers with a general, acceptable image of elderly people. Showing 
them as eccentric, stubborn, funny, stupid, active, respected, influential, strong or sexy, it shapes either affection or contempt for representatives of this group (Bell, 1992, cited in Nelson, 2003, p. 225). Consequently, the way of presenting old age in the media has social consequences outside the small screen.

When it comes to the definition of "old age", a peculiar chaos may be observed in the reference books. According to Antonii Kępiński (1983), this notion is impossible to define, because life itself is hardly possible to characterize (p. 159). To put it simply, ageing can be defined as individual, "natural, irreversible process of organ changes which accompanies the passage of time" (Kropińska, Trap, \& Wieczorowska-Tobis, 2009, p. 51). For the purposes of this work an extended definition, proposed by Agata Kowgier (2010), will be used. As the author suggests, "old age means (...) a stage of human life, in which unfavourable changes connected with debility and lowered psychophysical efficiency are accompanied by changes in social rank, material status, professional activity and family situation, which may influence one's personality, lifestyle and the quality of life" (p. 23).

\section{PORTRAIT OF AN ELDERLY MAN}

The beginning of old age is usually determined by a number of years. Nevertheless, there is no universal, commonly recognized periodization of this time (Nowicka, 2008, p. 18). As the end of old age is relatively easy to determine, because it is marked by death, there is no agreement on the beginning of this period (Straś-Romanowska, 2000, p. 264). For the majority of gerontologists, the period between the ages of 60-65 is regarded as the beginning of the late adulthood (Stuart-Hamilton, 2000, p. 19). It appears extremely important to emphasize the great internal diversity of this group. Therefore, the period of old age is often divided into sub-periods, although there is no consentaneous stand on this issue in the scientific community. In accordance with the postulates of the World Health Organization (WHO) it is possible to distinguish: middle age (45-59), older age (6075), old-age (75-90) and ripe old age (above 90), also called longevity (Kasperek-Golimowska, 2008, p. 31). In spite of the fact that chronological age classification has an indisputable advantage, which is the easiness of its application, ageing is too complex a phenomenon to become a part of strict guidelines (Vigué, \& Villalobos, 2007, p. 8). Chronological age is arbitrary and not very specific. The use of a precise number would give falsely objective significance of this issue. Consequently, a holistic approach to the ageing process, including changes on the biological, psychological and social level, seems to be essential.

Theories of ageing and old age. In developmental psychology there are numerous coexisting concepts explaining the ageing processes of human beings, which may be divided into two groups: theories concentrating on the biological aetiology of this process and theories analysing its psychological and social conditioning (Steuden, 2011, pp. 32-33). Due to the specificity of this article, the latter theory will be broadly examined.

The idea of activity introduced by Robert J. Havighurst is one of the psychosocial concepts devoted to elderly people (1972; 1953, cited in: Stelcer, 2009). The 
author claims that people in their entire life course (in all of the six phases) must perform certain developmental tasks in order to get satisfaction and welfare in his or her old age. It is highlighted that maintaining one's activeness and fulfilling specified values is essential in middle age. Thus, lowering efficiency of elderly people should be delayed, so that one can take an active part in social life as long as possible (pp. 10-15; pp. 10-31, cited in: pp. 11-12). This theory assumes that the elderly are productive and active people (Pikuła, 2011, p. 206) who sustain existing values and patterns and compensate the lost social roles with the new actions (Leszczyńska-Rejchert, 2010, p. 56).

Disengagement theory formulated by Newell E. Cumming (1960, cited in: Stelcer, 2009) is the next view concerned with ageing. It assumes an apogee of the functioning of a human being in their middle age, preceded by growth and followed by gradual withdrawal from social activity and currently performed roles for the sake of turning inwards. Supporters of this approach claim that achieving success in the last period of life is connected with approval of the inevitability of withdrawal from social life (pp. 23-24, cited in: p. 12).

Lars Tornstam (1997, cited in: Stelcer, 2009) formulated gerotranscendention theory claiming that old age is the time of growth of importance of transcendence in the life of human beings, that is, moving away from the external environment for the sake of individual internal world. In this theory, the existence of "constant spiritual growth of maturity and wisdom" is assumed, and gerotranscendention is "the last stage of the natural development directed at reaching maturity and wisdom" (pp. 55-63, quoted in: pp. 12-13).

On the other hand, the notion of Erik Eriskon presents ageing as "integral part of life space". According to the researcher it should be analyzed with regard to the context of one's entire existence - of their successes and failures. It is the time of existence summary. According to E. Erikson's claim, an older person is in the stage of integrity, in which he or she should accept their own past and the way in which it was experienced, proceed from concentration on oneself to the concentration on transcendence, as well as get rid of the fear of death and accept its inevitability (Sherman, 1981, cited in: Halicki, 2010, p. 15). While taking stock of one's own life, the reminiscense natural for this developmental stage (concept of reminiscense by Robert N. Butler) seems to be helpful; it is the "frequent recalling of facts and events from the past" which activate reflections and are the source of other experiences (Butler, 1963; Dubas, 2000, cited in: Halicki, 2010, pp. 15-16).

In the concepts mentioned hereinabove, it is easy to notice the significance of wisdom and autoreflectiveness in the positive experience of old age and solving developmental crises connected with it. Traditional identification of the seigniorial age with increased experience, stores of knowledge and abilities of distancing oneself from trivial problems of the present time, is confirmed by scientific theories.

Biological and psychological changes resulting from the ageing process. $\mathrm{Hu}-$ man body, during the ontogenesis, undergoes continuous transformations. As we already emphasized, ageing is "a resultant of various processes". (Helms, \& Tur- 
ner, 1999, p. 10). In the context of old age, physiological regress is underlined, since it causes lower productivity and efficiency (Błachnio, 2002, p. 15). In this period anabolic processes are dominated by catabolic ones. A human being undergoes gradual decline in physical condition caused by a fall in immunity and adaptability to new conditions, and an increase in susceptibility to stress factors (Steuden, 2011 , p. 32). In consequence, it leads to the impairment of organs and systems which is revealed by greater susceptibility to illnesses (Szarota, 2004, p. 23, cited in: Mielczarek, 2010, pp. 16-17). However, this process is strongly individualized. A lot of elderly people can pride in excellent shape (Mielczarek, 2010, pp. 16-17). Amid seniors it is possible to distinguish those who are self-sufficient, the partly dependent on others, and the completely dependent upon the environment (Vigué, \& Villalobos, 2007, p. 254).

Amid seniors, apart from undeniable biological changes, transformations connected with personality, subjective experience, and psychological processes take place (Nowicka, 2008, p. 19). Exaggerated and even grotesque sharpening of their features occurs. A great number of people demonstrate the lack of the emotional stability. Moreover, a current ability of remembering becomes distorted. Although elderly people recall events from thirty years ago with affection, their short-term memory becomes less and less efficient. The attitude to changes of senior citizens is hardly ever optimistic. They are afraid of the unknown. In consequence, they demonstrate lower flexibility in many areas of activity (Pikuła, 2011, pp. 22-23).

Elderly people's attitude to themselves. Old age of other people can be seen primarily through losses, rather than profits. It is connected with the fear of illnesses, fall in activity, loss of beauty, and worsening financial situation. However, one's own old age is judged positively. The oldest people examined by Jerzy Halicki (2010) expressed contentment concerned with the fact that they have lived to a great age. They claimed that they accepted the fact of ageing, but, on the other hand, they were pleased that they did not look their age. Although elderly people consider their medical condition mainly as average because of various ailments, they understand it as the natural state of affairs (pp. 232-234).

Elderly people's attitude to the real world. Elderly people complain about the young's animosity to devote their time to conversation. They feel uncomfortable when they are forced to ask strangers for help. Some of the elderly find it frustrating to ask for assistance even close members of their families (Halicki, 2010, p. 301).

Surrounding's attitude to elderly people. Old age is seen through the numerous stereotypes which distort the image of elderly people (Kowgier, 2010, p. 68). In consequence it contributes to the stigmatization of seniors. It strengthens and justifies ageism (Tobias-Adamczyk, 2007, p. 37) - "negative stereotyped social attitudes towards older persons". It is visible in the ways in which institutions and individuals treat elderly people, as well as in the media, language, jokes and the like (Janiszewska-Rain, 2005, p. 612). Senior citizens are treated in the more evil, unfair, demeaning way. Their needs are not met sufficiently, because they are regarded as less useful than energetic youths. In contrast to the other groups they 
have a hampered access to power, income, health, education and prestige (SzaturJaworska, Błędowski, \& Dzięgielewska, 2006, pp. 216-217).

In Poland, according to studies by Ewa Miszczak, typical elderly person is: decrepit, poor, lonely and dependent (Miszczak, 2006, pp. 305-312 cited in: Pawlina, 2011, p. 141). Following the research done by D. E. Schmidt and S. M. Boland, it may be stated that in American society the following stereotypes concerning old age are current: "model grandfather, wise man, liberal father of the nation, weak, defenceless, lonely man, nosey neighbour, discouraged, tramp, nasty person and miser" (Tokay, 2000, p. 24, quoted in: Pawlina, 2011, p. 141).

It is claimed that although elderly people have greater knowledge and more experience, their thinking is definitely slower than the one of young persons (StuartHamilton, 2000, p. 44). They are believed to be feckless and unable to work. Even though they require permanent help and care, they seclude themselves from family and friends (Pawłowska, \& Jundziłł, 2006, p. 42). They are demanding, Neanderthals, touchy about the condition of their health (Szatur-Jaworska, Błędowski, \& Dzięgielewska, 2006, p. 218). According to the universal view they are marked by greater susceptibility to stress - it is difficult for them to take control over it. Moreover, their ability to deal with problems is worse (Denmark, 1999, after: Mielczarek, 2010, p. 23). Elderly people are supposed to be naive, backwards, deprived of a reason of life. They are heavy burden not only for their families, but also for the society (Nelson, 2003, p. 242). It is generally believed that in the course of time, life satisfaction is reduced, which leads to concentring on the past (Frąckowiak, \& Straś-Romanowska, 2008, p. 33).

In spite of many negative features, it is believed, that seniors are cheerful, polite, influential, clever, trustworthy, have political power and a considerable freedom of action. They make an effort to keep the fleeting youth (Palmore, 1990, cited in: Kołodziej, 2008, p. 65). Therefore, it is absurd to believe they have reduced desires concerning, for instance, sexual needs. The majority of pensioners still lead an active life. The age, in contrast to predominant opinions, did not turn them into asexual beings (Mielczarek, 2010, p. 171).

For Donald Helms and Jeffrey Turner (1999) the discriminating attitude was developed in the period of socialization (p. 528). From the research of Sylwia Kropińska et.al. (Kropińska, Trap, \& Wieczorowska-Tobis, 2009) we can get to know that percentage of discriminated elderly people in Poland, as well as in many other countries is considerable. With no doubt, it is caused by the cult of youth propagated in the past years by mass media (Kropińska, Trap, \& Wieczorowska-Tobis, 2009, p. 59).

Functioning of elderly people in different roles and contexts. Being a spouse is one of the roles performed by elderly people. As J. Halicki states, the research shows that men talk about their wives with affection and approval much more often than women about their husbands. Even though women are a bit less contented with their marriages, in general, both sexes feel satisfaction (Halicki, 2010, p. 229).

The elderly act also as friends, acquaintances, although the social network is diminished in this time as a result of such factors as retirement. Establishing new 
acquaintances is for elderly people less frequent. Nevertheless, they are particularly concerned about social relations they already have (Halicki, 2010, p. 300).

On the threshold the spiritual sphere is especially important for people. Being members of a community, practising a particular religion, people are provided with support and sense of security, which raises the quality of seniors' lives (Halicki, 2010, pp. 231-232).

\section{TV SERIES AS ROLE MODELS AND EDUCATIONAL MEANS}

From the very beginning, TV series ${ }^{1}$ have enjoyed unremitting popularity both in Poland and America. Many researchers looked for grounds for such great interest in this new phenomenon of pop-culture. Moreover, they took into consideration the phenomenon of seriality as a general issue (e.g. Lewicki, 2011).

Attractiveness of series is often considered through their resemblance to everyday life. Emotions and problems of fictional characters play compensating roles experiencing them through the identification with characters presented on screen makes up for shortcomings (Skrzypczak, 1995, p. 491). That is why series have become an acceptable substitute for everyday life (Melosik, 2003, p. 77 cited in: Mazurek-Lipka, 2012, p. 145), the contemporary "bible for poor", which can successfully satisfy the need of narration (Skrzypczak, 1995, p. 490). In series the main role is played by dialogue - very often the set and environment are the same for many episodes, so that the surrounding is not as important as ongoing talks: "Characters in series condensate, talk platitudes, 'let the steam out'” (Szkudlarek, 1999, p. 93, quoted in: Zierkiewicz, \& Anioł, 2012, p. 147). Problems mentioned in series concern both universal issues and current problems, provoking public debate, hence series "can serve as a model - teach how to live in the modern world. This type of socialization influence (modelling) not only informs viewers about the existence of a certain social problem, but also gives a certain pattern of behavior for people who currently face it" (Pater, 2002, p. 174). That is why series can be called "pro-social" - they present important issues of social life which were so far considered taboo (Godzic, 2004, p. 39). They can be regarded as a "stylistic training ground" - the place where sensitive, unfavorable topics are discussed (Lewicki, 2011, p. 34) . "Pro-social activity" of series is usually limited and very often only touches and indicates the problem - in reality the scenes are very conservative, conventional, maintaining the cultural status quo (Kisielewska, 2006, p. 320).

Even though some researchers perceive the educational role of series as belonging to the age of paleo-television (Skrzypczak, 1995, p. 491), it is not possible to omit the fact, that in current times "the world of television shapes objective reality rather than reflects it. Media are superior to objective reality. Therefore, it is a situation where television's vision of reality has stronger influence on the social world and creates it more than ever before" (Bogunia-Borowska, 2012, p. 309). Therefore, "the educational potential of series should be widely understood - not only as bringing up a particular system of values, giving the useful (lively - useful) information and drawing up the

The first American series were produced in 1912 (Skrzypczak, 1998, p. 230), and in Poland in 1965 (Banaszkiewicz-Zygmunt, 2000, p. 198). 
model of social role, but also as 'implementation' of specific ways of a narrative and, as a result the experience the world" (Zierkiewicz, \& Anioł, 2012, p. 149).

\section{OLD AGE IN POP CULTURE AND MASS MEDIA - CURRENT RESEARCH}

The problem of presenting old age in pop cultural texts is not a new issue - many publications have discussed that subject in series, adverts, movies, the press, as well as photography. According to Małgorzata Król (2006) “The elderly are portrayed in the traditional way. A role of consumers is assigned to them they are perceived as receivers of insurance or different medications increasing the vitality (...), experts, advisers and also as grandmothers and grandfathers" (p. 27; Podsiadła, 2009, p. 219; Łyszkowska, \& Sojka, 2005, p. 184-186; Wysocka, 2005, p. 191; Garncarek, 2005, p. 201-204; Chmielewska-Łuczak, 2002, p. 114116). In the media old age is also underrepresented - it is happening in spite of the appreciable increase in the participation of the elderly in the demographic structures of societies: in Poland in the years 1988 - 2002 the population of people above 65 increased by 31.9\% (Sobczak, 2011, p. 32), and in the USA in the years 1950 - 2009 the rate of retired citizens grew from 8.1 up to $12.8 \%$ (Shrestha, \& Heisler, 2011, p. 13). The presence of the elderly in the real world and their growing number is not transferred into the world of the small screen - fewer than $2 \%$ of characters of TV series and movies broadcast in the prime-time are people above the age of 65 (Butler, 2006, p. 12). According to Edyta Łyszkowska and Agnieszka Sojka (2005) the natural old age does not have any chances to appear in the media (p. 187). Dominating nowadays cult of youth treats old age as unnatural phenomenon, effect of negligence or illness (Zierkiewicz, 2005, pp. 227-230). Therefore "old age was removed from collective imagination. Being out of keeping with fantastic axioms of present time, flabby bodies can only scare in nursery homes. In the world of mass media, young, preferably naked and supple body rules" (Czaja, 1994, p. 74 quoted in: Ratkowska, 2006, p. 139). That is way, the elderly are not the best characters to occur in contemporary pop culture texts (compare Podgórski, 2009, p. 159). Currently, in the public sphere, old age is usually "improved" - older people are presented as active, socially engaged and healthy (Robbins, 2005, p. 232). It is easy to notice that in mass media old age is very often discriminated, mocked and caricatured. This is not a new phenomenon - ancient Greeks parodied indispositions of the senior age. Those issues which were perceived as inappropriate and unsuitable to elderly played special roles, e.g. all signs of still active sexuality, and desire for being attractive by taking care of the body shape and clothes (outfit). They were also repeated in the following ages (Beauvoir, 2011). Elderly people in feature films and series are portrayed as "pushing, malicious and very possessive" (Garncarek, 2005, p. 202) or "beastly" characters, venting their frustration on others (Wysocka, 2005, p. 190). In the youth magazines "older women (...) are stupid, sclerotic, blind, deaf, decrepit, weak, malicious, beastly, old-fashioned, uninformed. They have no interests and do not take extra activities (...). They do not have dreams or 
plans, it seems that they also have no emotions, it is not difficult to ridicule and neglect them" (Łysak, 2005, p. 217). It is an important aspect that older women show up more rarely than older men in films or series and usually do not play the leading parts (Garncarek, 2005, p. 200). Older men are introduced through the prism of the prestigious competition which they performed before, in contrast to older women, who are presented as caring grandmothers, minders and guardians of the home life (Podsiadła, 2009, pp. 219-220).

The problem of the constantly increasing population of elderly people in highdeveloped societies will certainly not be possible to ignore, oversight or omit in the future. With no doubt, the popular culture has a substantial role to play in that subject matter: further treatment of the old age as undesirable and wrong must be replaced and give a room to gradual introduction "into the space of postmodernist reality, demanding respect" (Podsiadła, 2009, p. 129).

\section{CRITICAL IMAGE ANALYSIS OF OLD AGE IN POLISH AND AMERICAN TV SERIES}

Making an attempt to analyse chosen TV series, we settled them in a critical paradigm, in accordance with the assumption that pop-cultural texts examined by us contain a hidden form inaccessible to the viewers. Taking into consideration the fact that series shape attitudes, serve as models, bring important social issues up, provide models of solutions and ways of understanding reality, we wished to discover in what ways media products chosen by us create the image of old age, and thereby - participate in creating a perception of it. The aim of our investigations was the qualitative and quantitative analysis of the current image of old age found in series. The study areas of conducted analysis concentrated around the following questions:

- In what kind of roles and in what context are elderly people presented?

- What is the nature of the plot in which the old people occur?

- What is the attitude of elderly people to themselves, other people and the world?

- What is the attitude of other characters of series to seniors?

- How often are the old people shown in series?

There were three main criteria which were chosen by us to select the programs to analyze: time of emission (both "historical" as well as airtime), type, and popularity. Due to the nature of the issue we decided to choose dramas', where as an indicator of popularity we picked the number of their audience. The series had to be up-to-date, showed within last few years and showed in the so-called primetime, that is "presented to the audience in best air time: (...), between $8.00 \mathrm{p} . \mathrm{m}$.

As Taylor and Willis notice (2006), "at least kinds are genres, clear borders of them are never determined" (p. 62). A similar ambiguity appeared in the American production chosen by us "Desperate Housewife" - the series is described simultaneously as a comedy of manners and drama. However, further quoted authors notice that "to assign a media text to particular kind is based on the presence of number of recognized elements" (p. 62). In "Desperate housewives" numerous family problems are brought up - partnership, parental, education, associated with the local environment, with remaining. 
and 11 p.m. and 4.30 p.m. and 6 p.m." (Bonikowska, \& Leska, 2009, p. 184). Considering all criteria, we chose American series "Desperate housewives" and Polish "Colors of happiness".

Characteristics of chosen series. "Colours of happiness"4 has been aired from 2007 in TVP2. Currently the series is broadcast on weekdays at 8.15 p.m. Episodes last about 25 minutes on average. Ilona Łepkowska is a leading scriptwriter and a producer of series, she is also author of scripts of the most popular Polish series, so such as "The L for Love" and "For better and for worse". The plot of the series is concentrating around many trends, out of which most important are the fates history of the family of Gordons, Zwoleński, Jakubowski, Rybiński and Jelen. Ratings of these series are in average for about 5 million viewers (Najpopularniejsze w TV, 2013; Seriale we wrześniu 2012 - wyniki oglądalności seriali - M jak MIŁOŚĆ ponad 7 MLN widzów, 2012; Wawrzyn, 2012). For the purposes of our study we have made the analysis of 35 episodes of the series.

"Desperate housewives" is the series of the authorship of the March Cherry, produced and broadcast by the station $\mathrm{ABC}$, being one of the three largest TV stations in the USA, next to NBC and CBS (Inderjit, 2009, p. 199). The series was shown between years: $2004-2012$, and its ratings fluctuated at that time from almost 22 to 11 million viewers (Oglądalność seriali w USA na jesień 26gru10, 2010; The Most Watched TV Shows, Season 2011-2012 [US Broadcast Nets.], 2012; Desperate Housewives na czele, 2006). The plot of the series is concentrating on the lives of the residents of the Wisteria Lane, located in a small town - Fairview. The main characters are Susan Mayer, Lynnete Scavo, Bree van De Kamp, and Gabrielle Solis - the group of close friends sharing common problems, joys, sorrows, and secrets. One episode of series lasts about 45 minutes. We analysed 23 episodes.

3 Although this series didn't comply with the requirements to the end of the popularity (was the second most willingly watched drama in Poland) we decided on its choice, because of the amount of literature already publicized devoted to the placed on the top of popularity series " $\mathrm{L}$ for Love". It was analysed in terms of models of the fatherhood (Sosnowski, 2007), the strategy of the addressing and the role of seniors families (Kisielewska, 2006), the image of an older women (Wysocka, 2005), of women's forms in the gerontological context (Mituła, 2006). The series was also analysed by Łaciak (2006).

4 The all information about series was taken from http://test.barwyszczescia.tvp.pl/, the official series website, date of access: 25.06.2013.

5 All the information about the series was taken from an http://www.filmweb.pl/Gotowe. Na.Wszystko, date of access: 26.02.2013. 


\begin{tabular}{|c|c|c|c|}
\hline 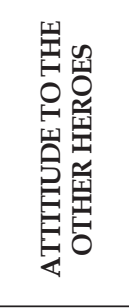 & 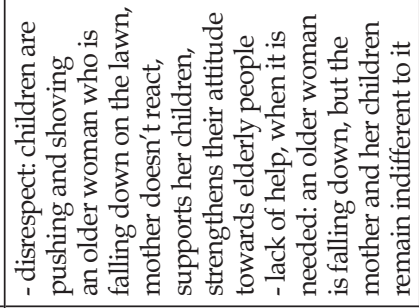 & 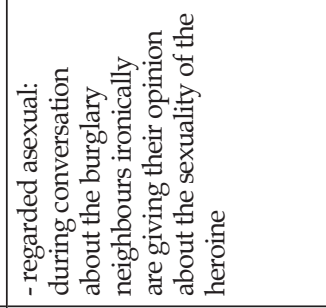 & 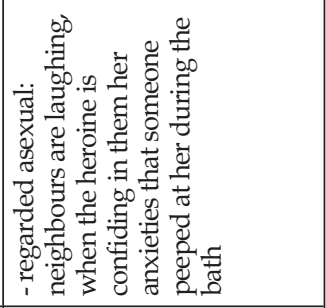 \\
\hline 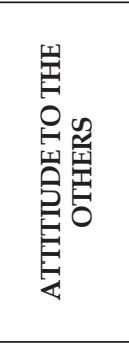 & 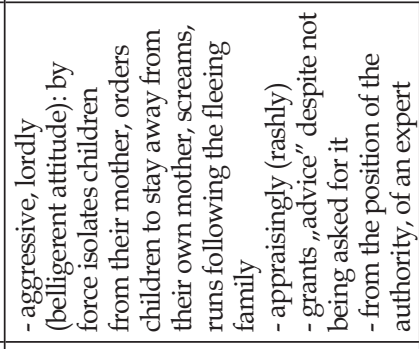 & 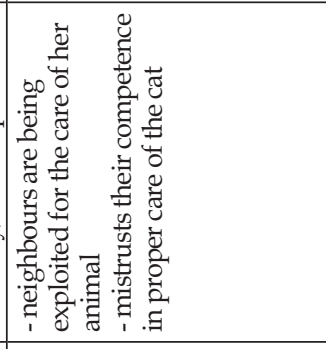 & 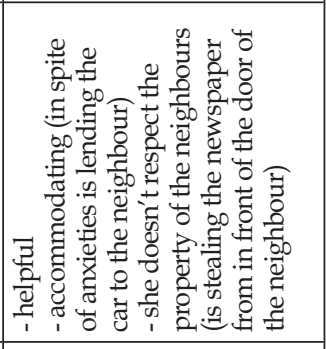 \\
\hline 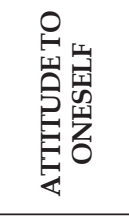 & 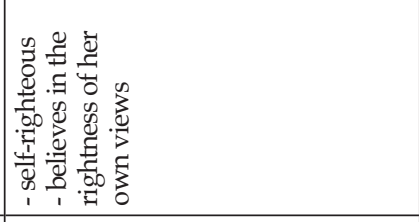 & & 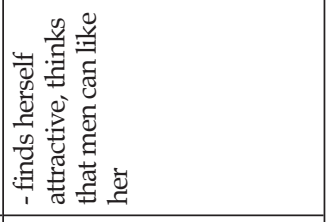 \\
\hline 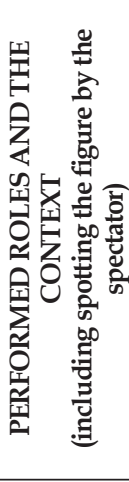 & 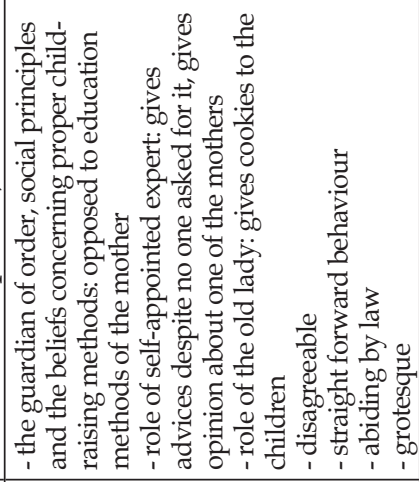 & 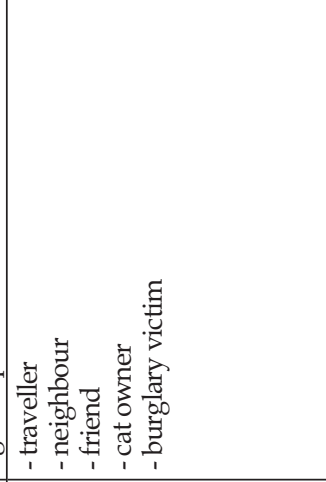 & 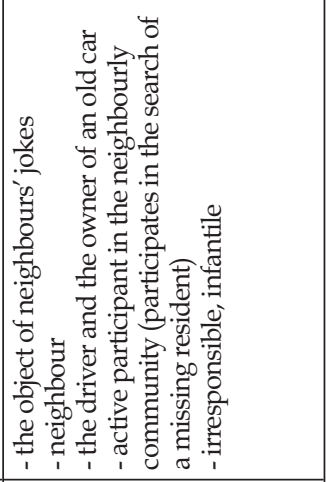 \\
\hline 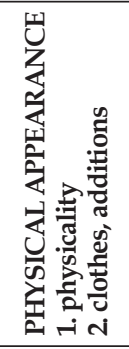 & 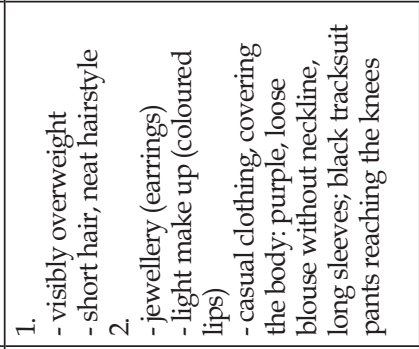 & 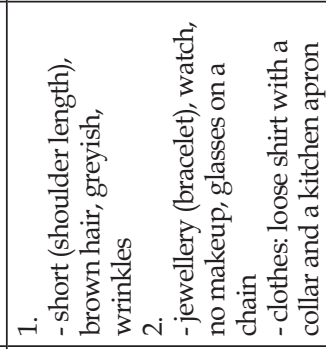 & 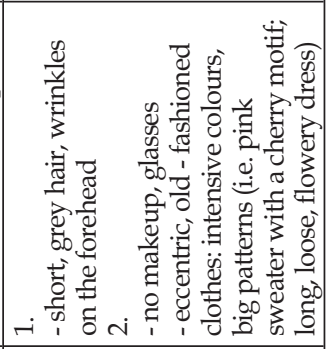 \\
\hline $\begin{array}{l}\text { 을 } \\
\text { 至 }\end{array}$ & 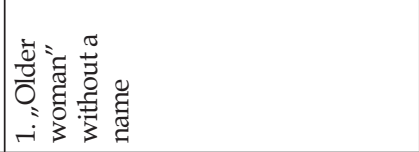 & 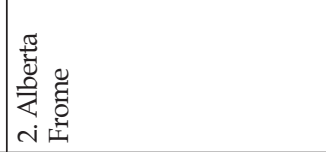 & 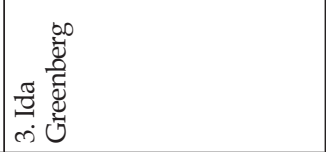 \\
\hline
\end{tabular}




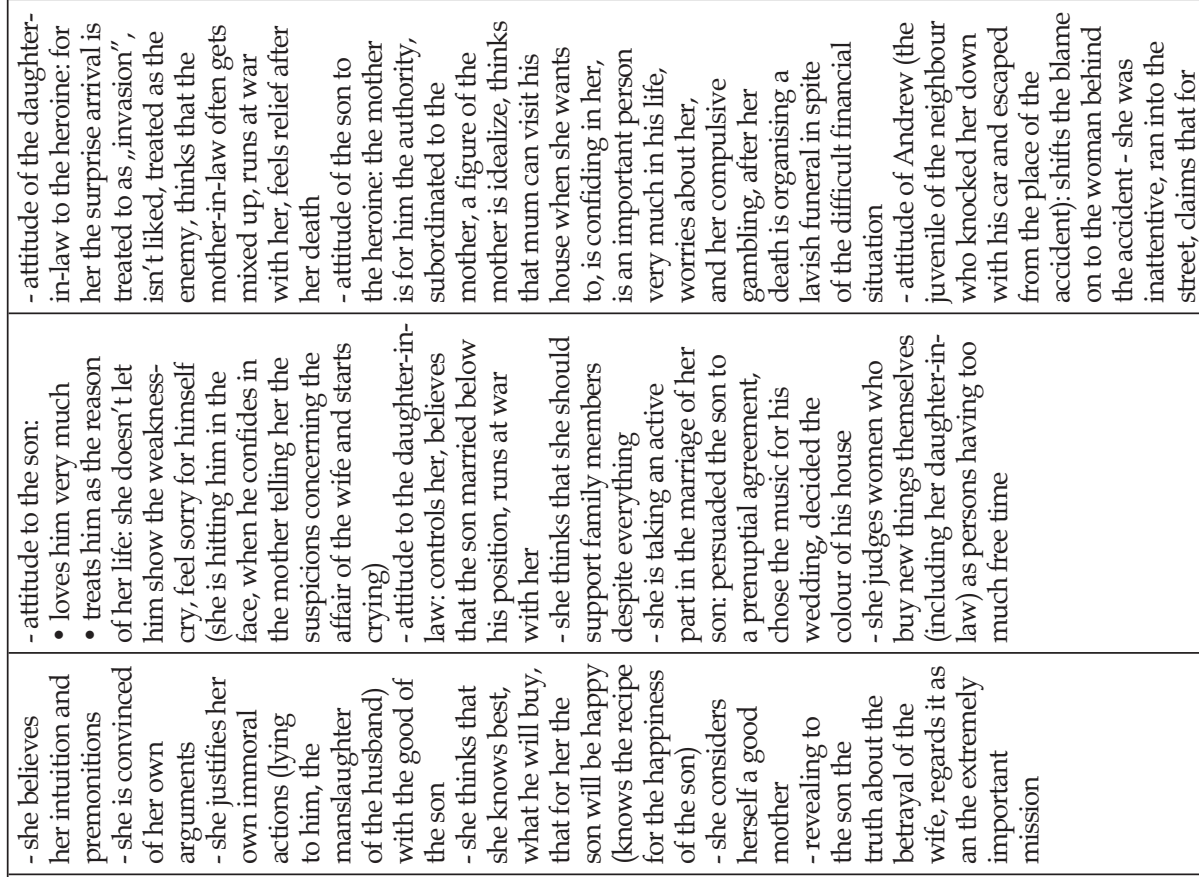

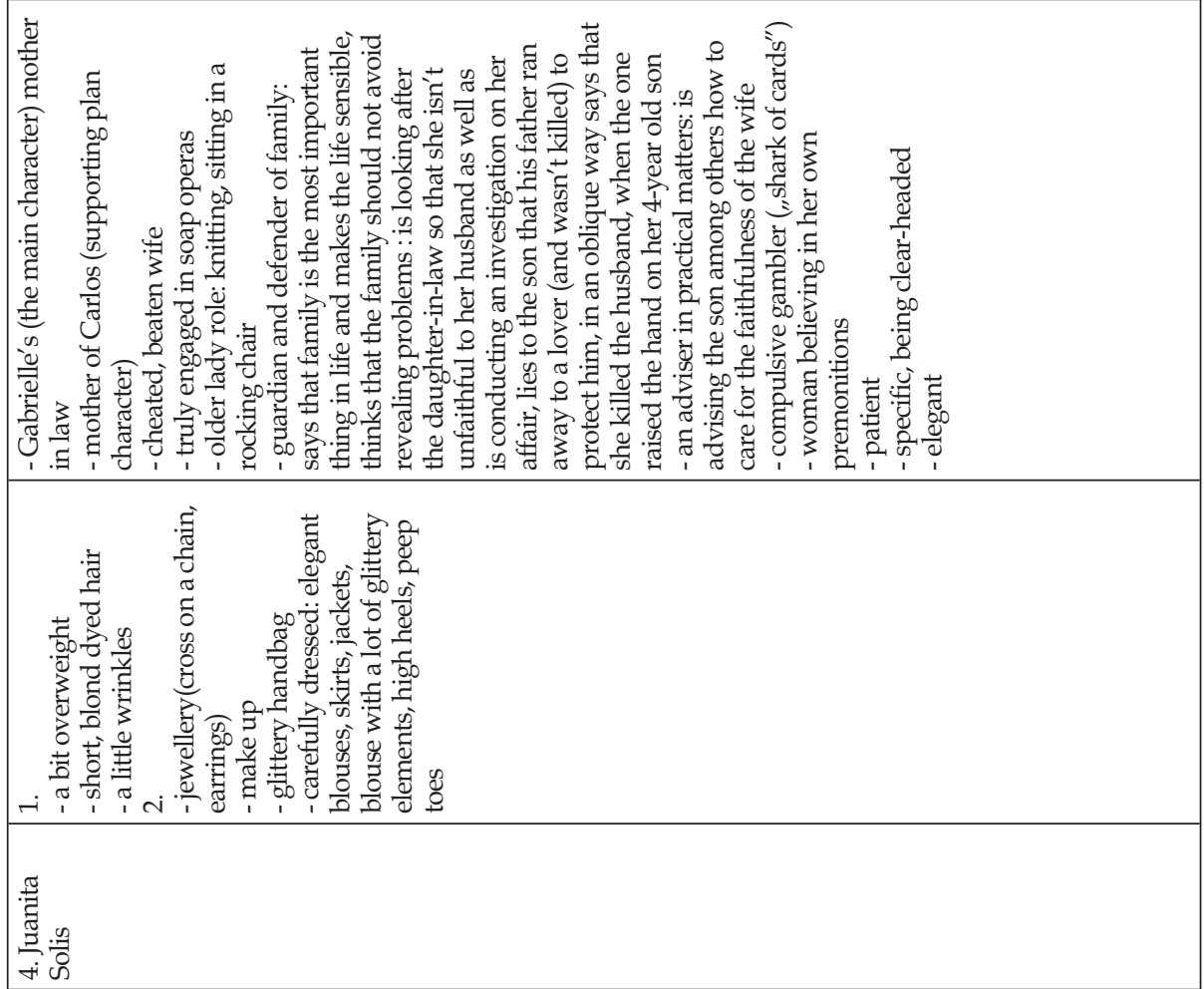




\begin{tabular}{|c|c|}
\hline \multirow{4}{*}{ 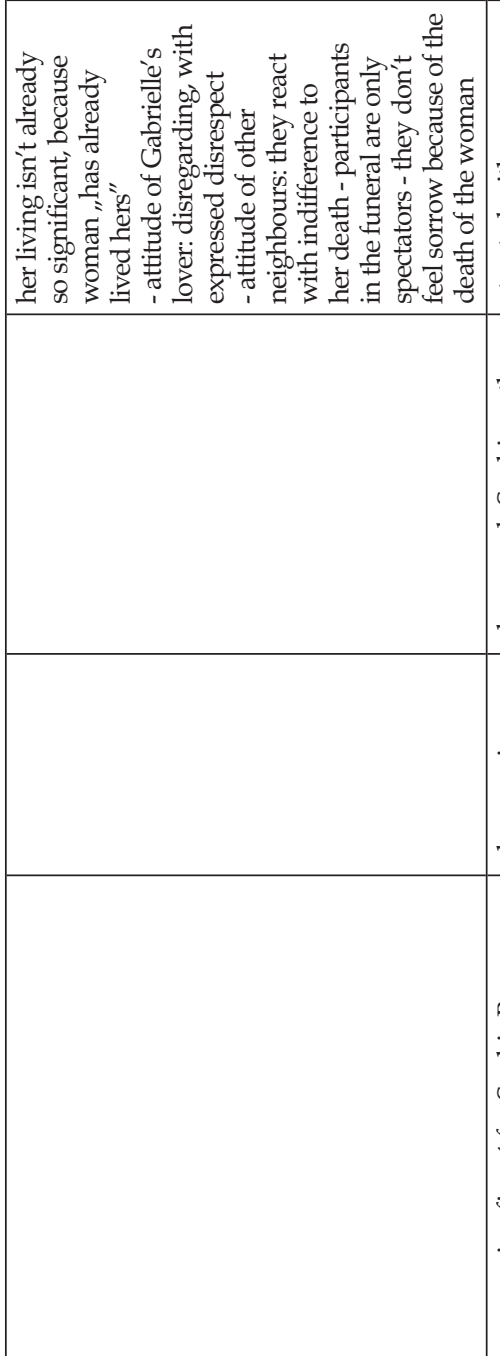 } & 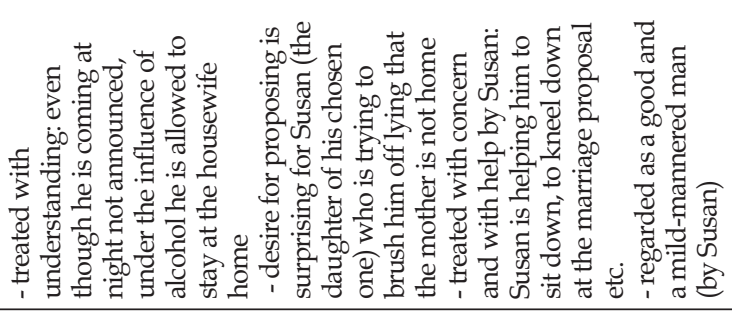 \\
\hline & 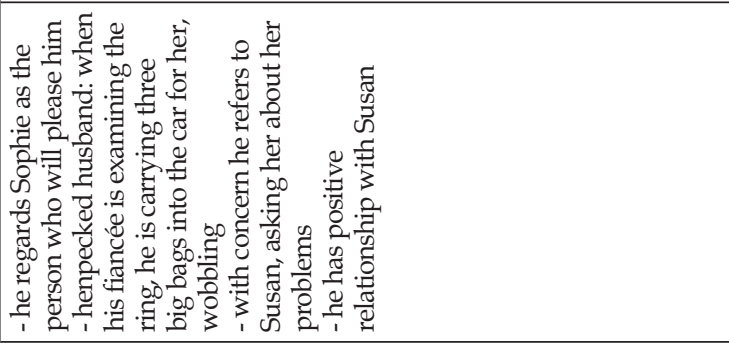 \\
\hline & 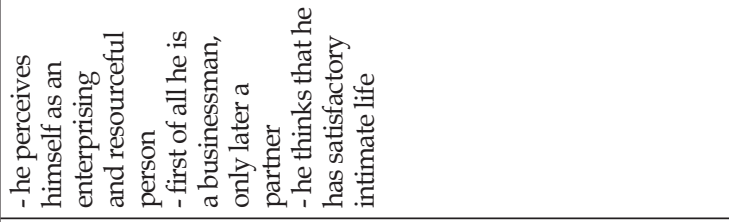 \\
\hline & 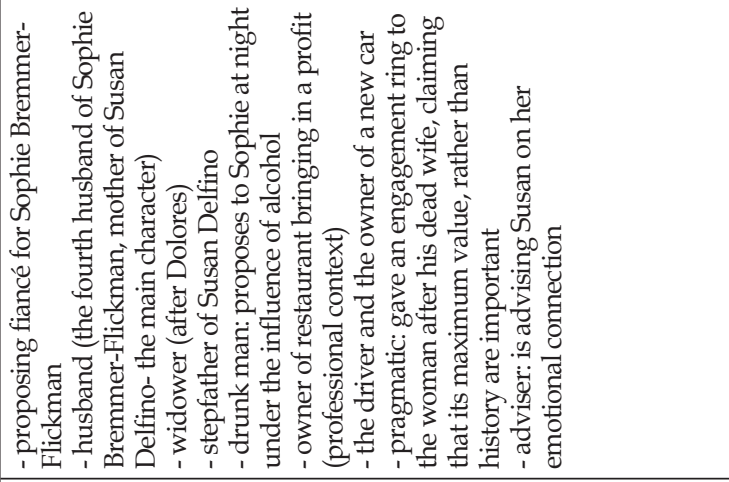 \\
\hline & 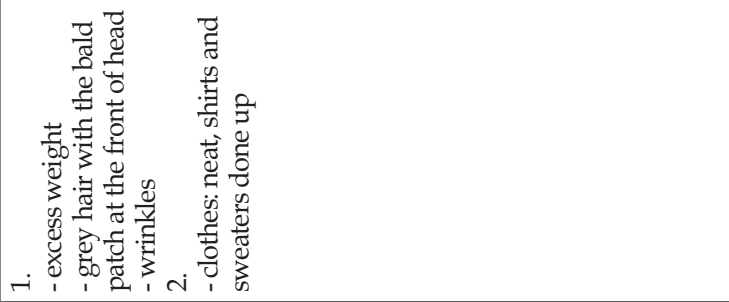 \\
\hline & 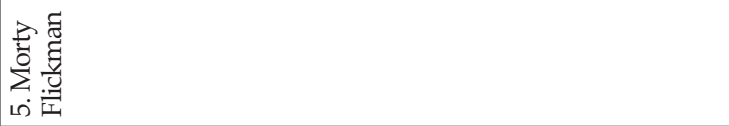 \\
\hline
\end{tabular}




\begin{tabular}{|c|c|}
\hline 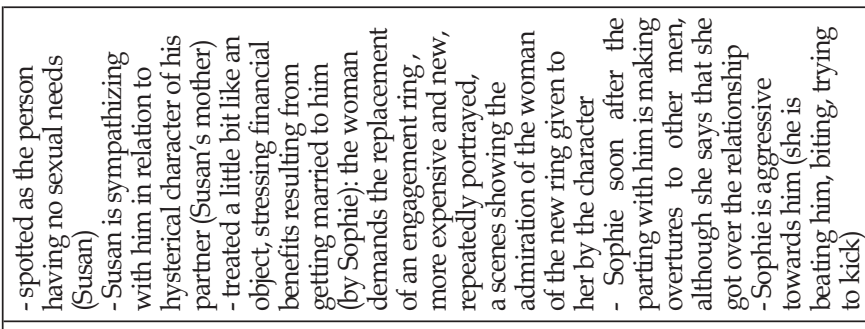 & 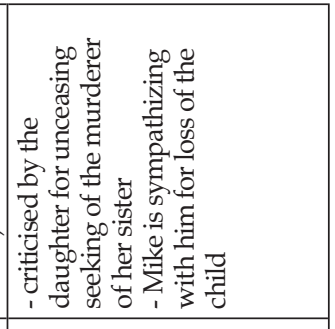 \\
\hline & 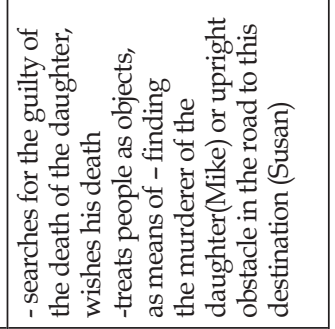 \\
\hline & 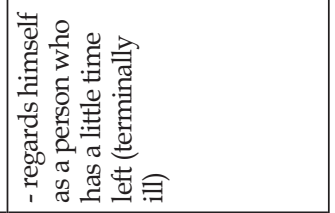 \\
\hline & 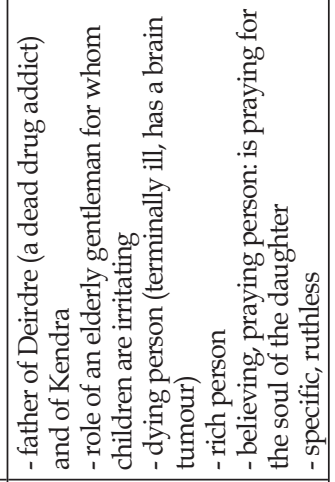 \\
\hline & 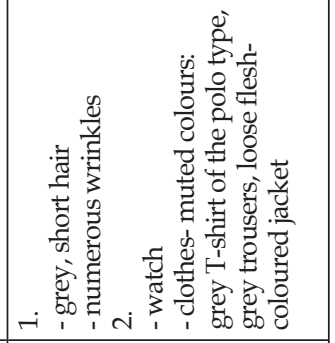 \\
\hline & 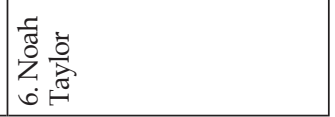 \\
\hline
\end{tabular}




\begin{tabular}{|c|c|}
\hline 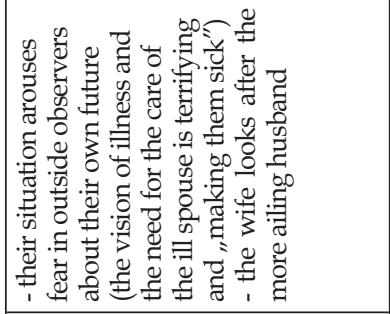 & 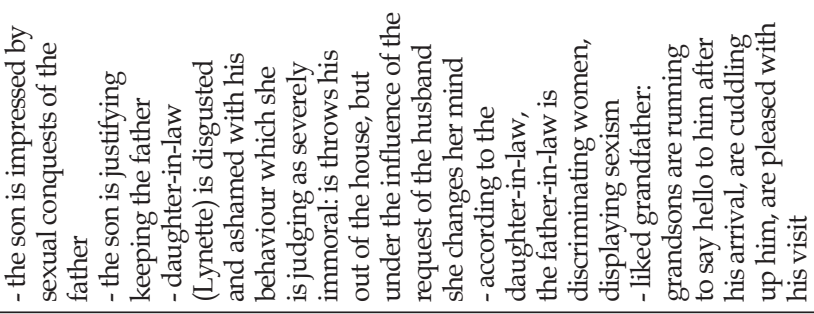 \\
\hline & 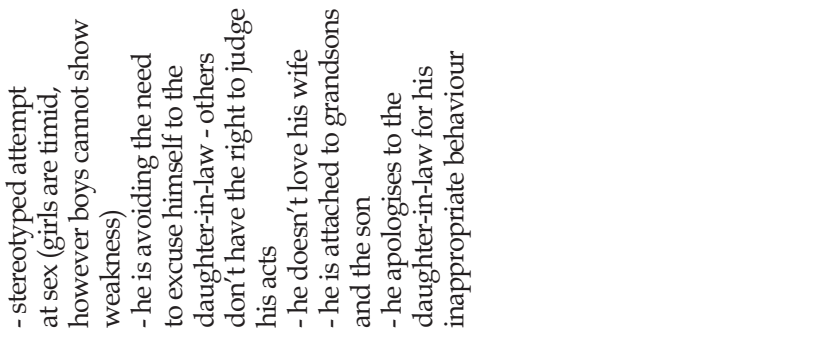 \\
\hline & 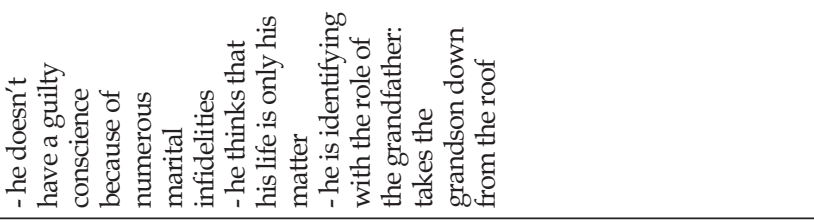 \\
\hline 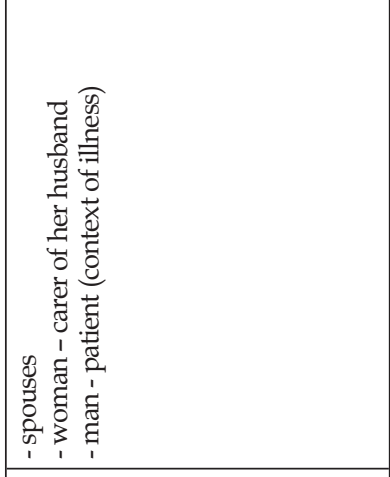 & 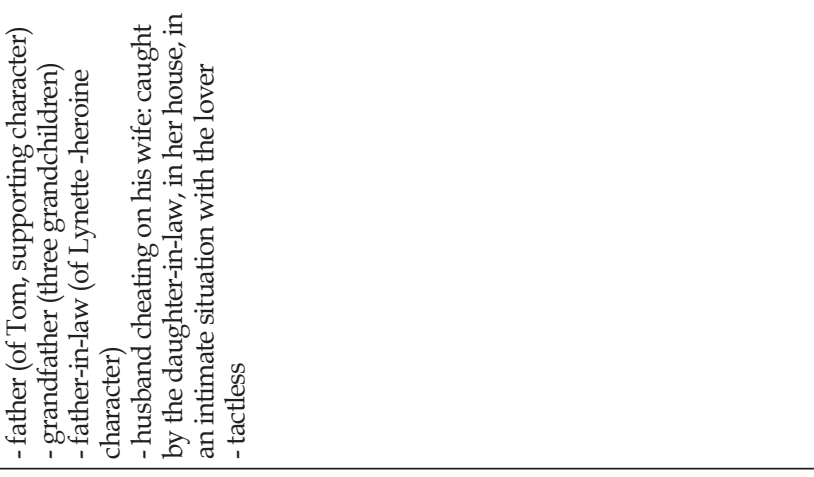 \\
\hline 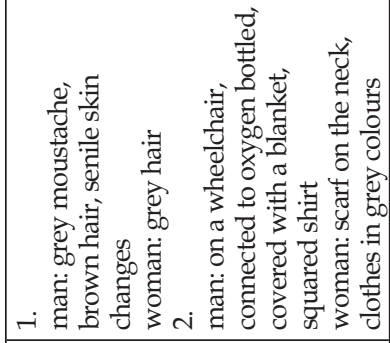 & 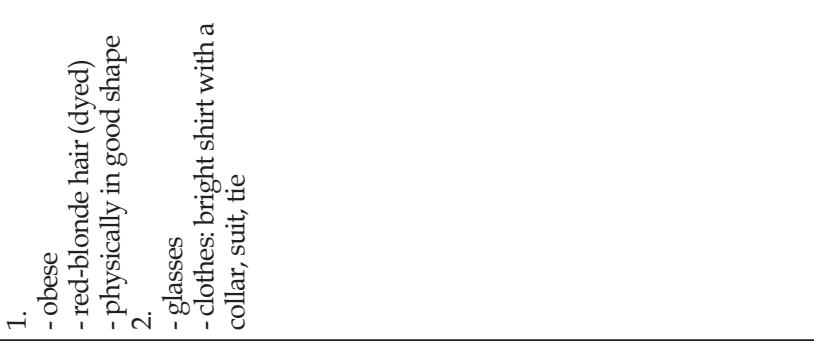 \\
\hline 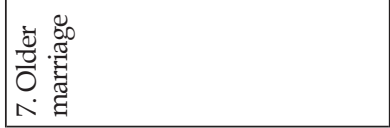 & 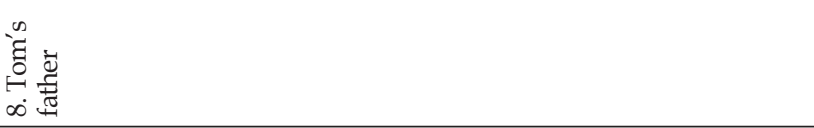 \\
\hline
\end{tabular}




\begin{tabular}{|c|c|}
\hline 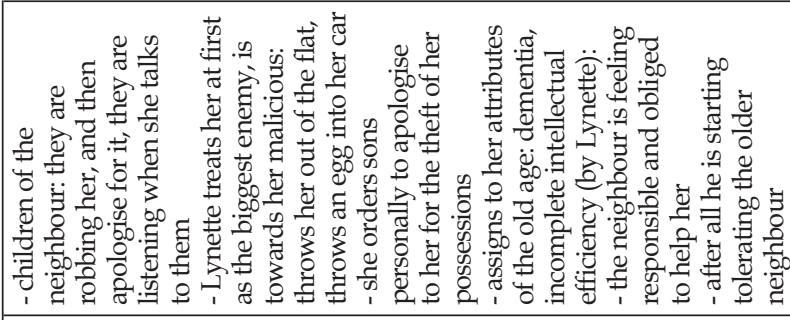 & 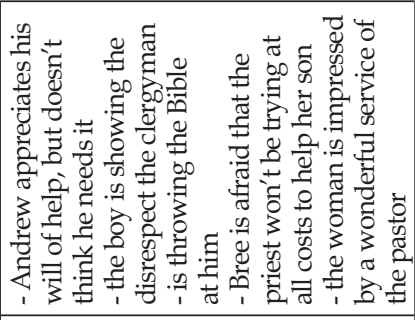 \\
\hline 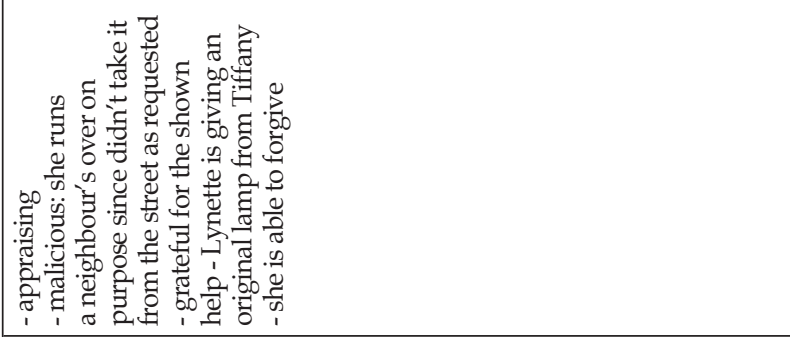 & 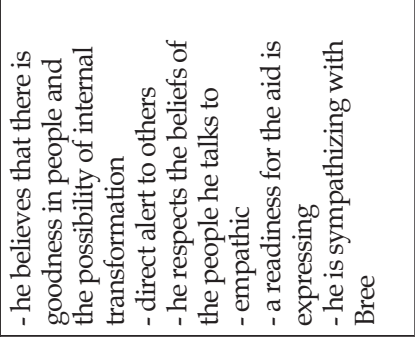 \\
\hline 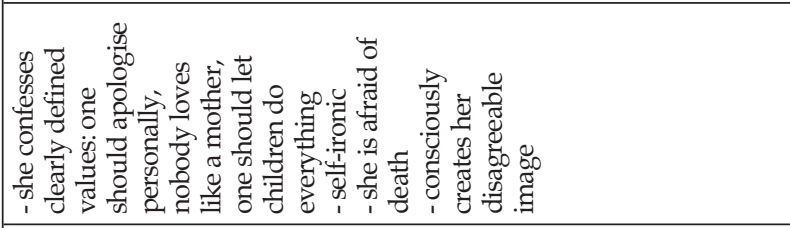 & 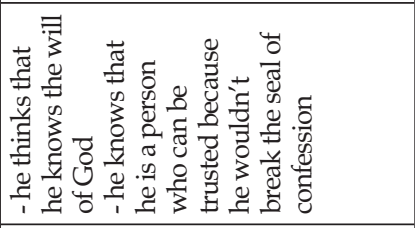 \\
\hline 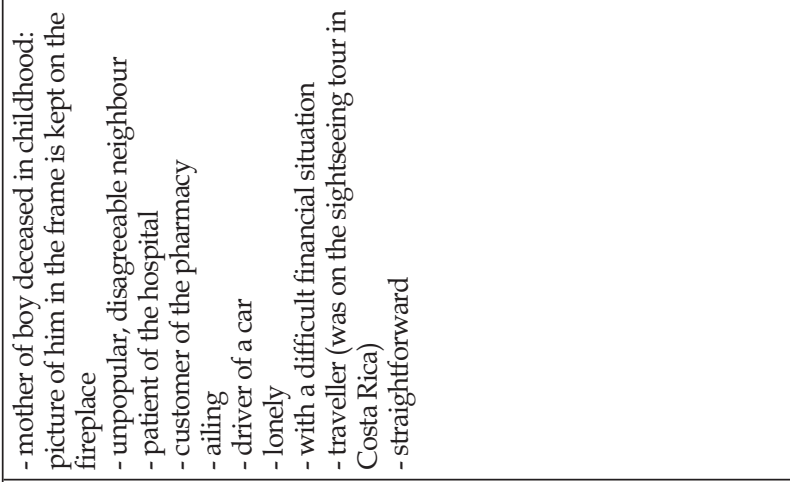 & 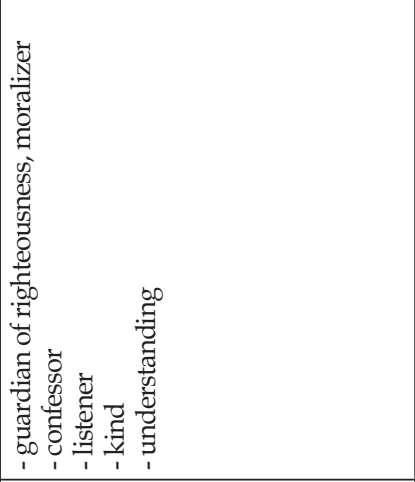 \\
\hline 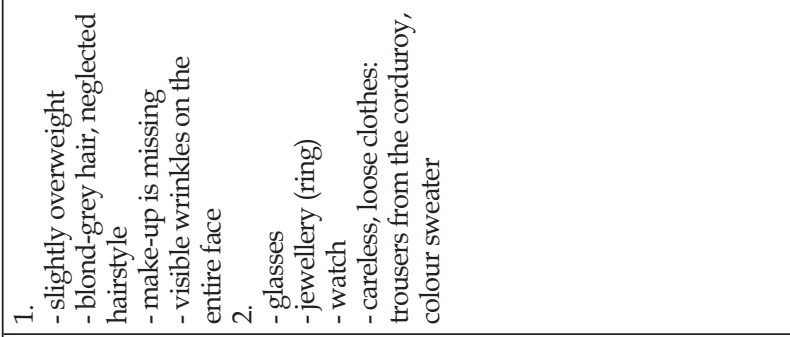 & 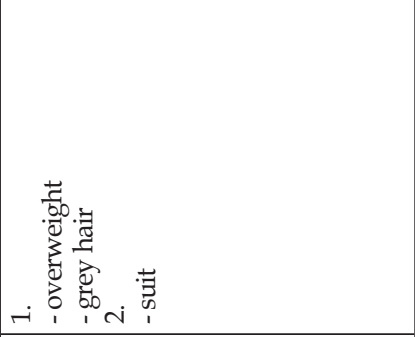 \\
\hline 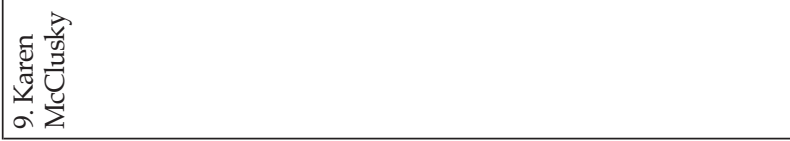 & 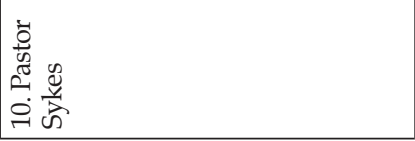 \\
\hline
\end{tabular}




\begin{tabular}{|c|c|c|}
\hline 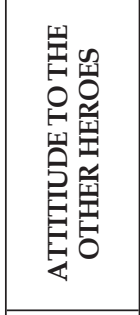 & 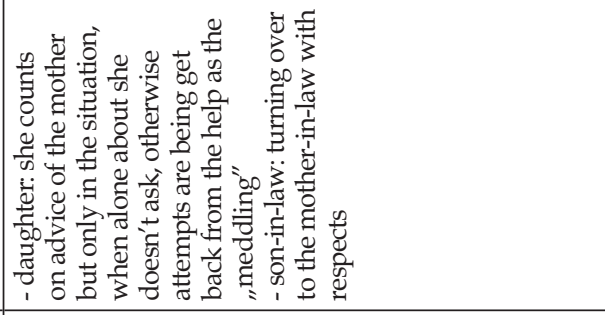 & 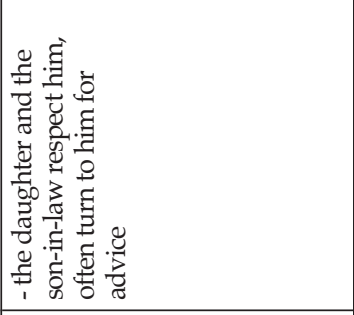 \\
\hline 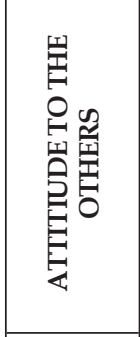 & 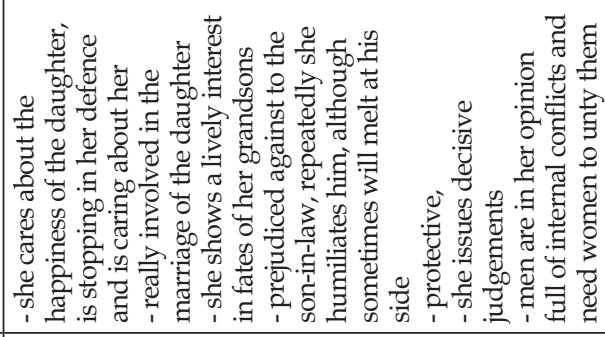 & 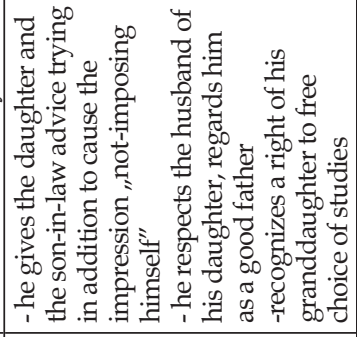 \\
\hline 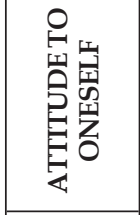 & 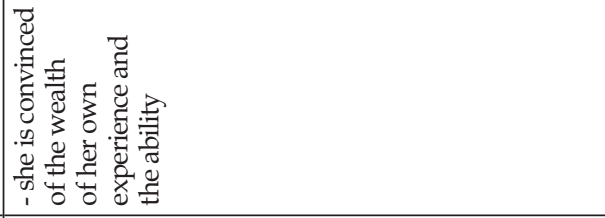 & 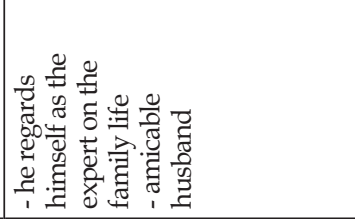 \\
\hline 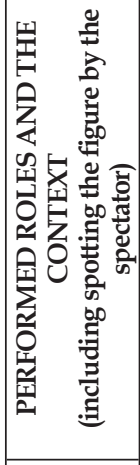 & 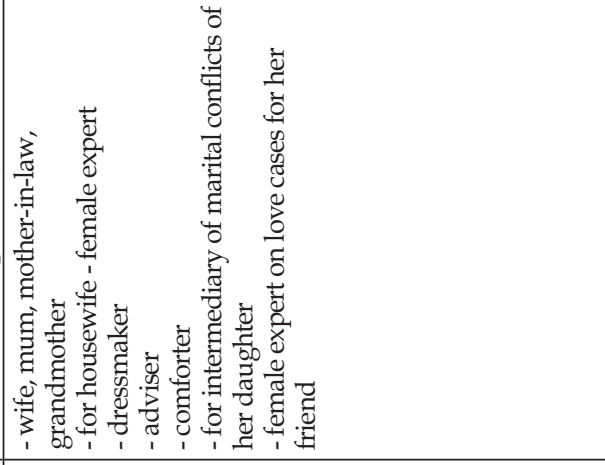 & 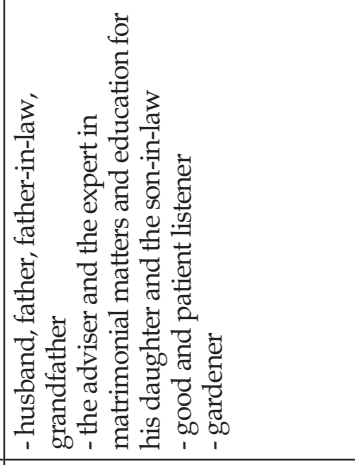 \\
\hline 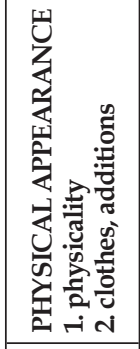 & 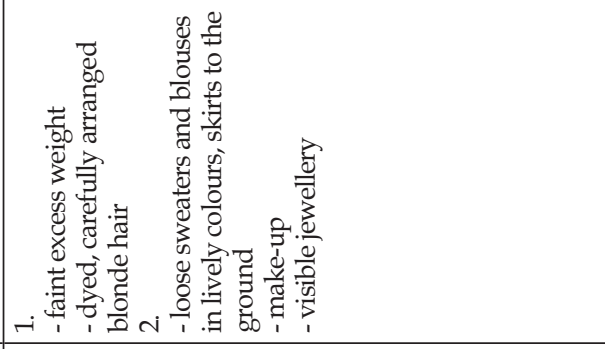 & 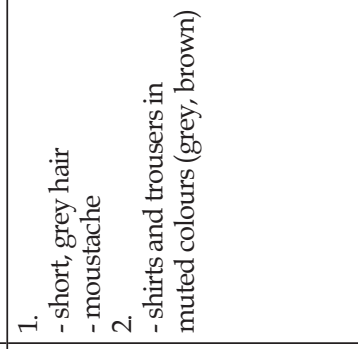 \\
\hline 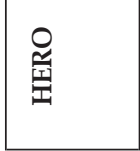 & 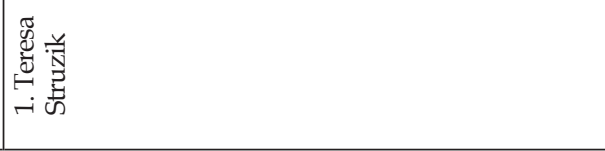 & 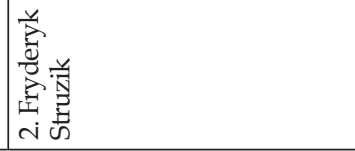 \\
\hline
\end{tabular}




\begin{tabular}{|c|c|}
\hline 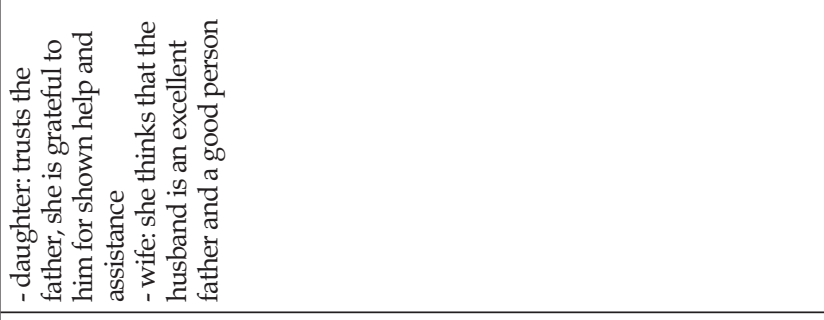 & 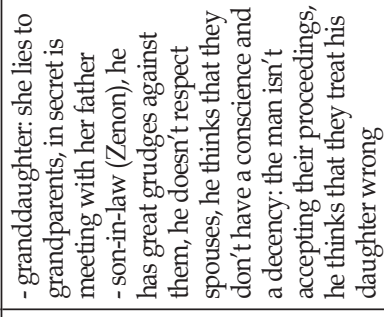 \\
\hline 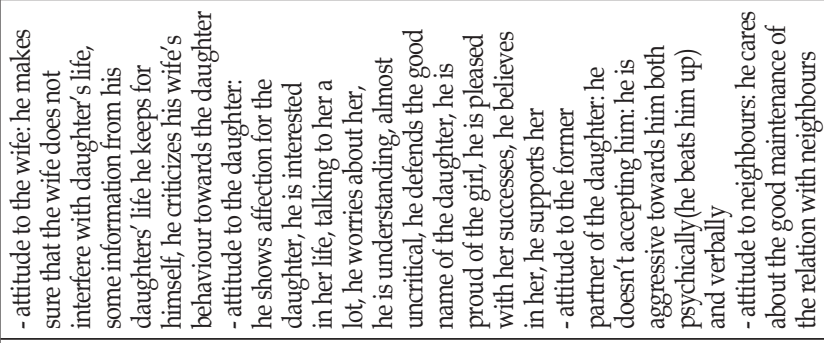 & 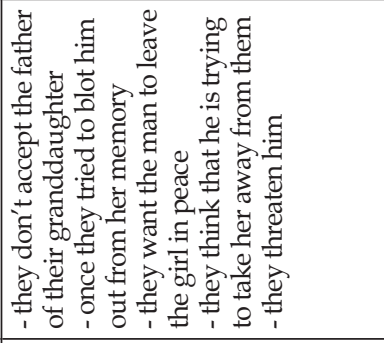 \\
\hline 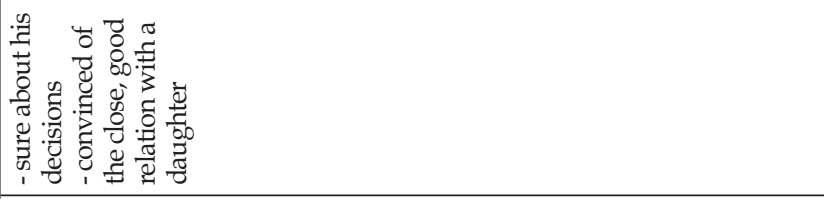 & \\
\hline 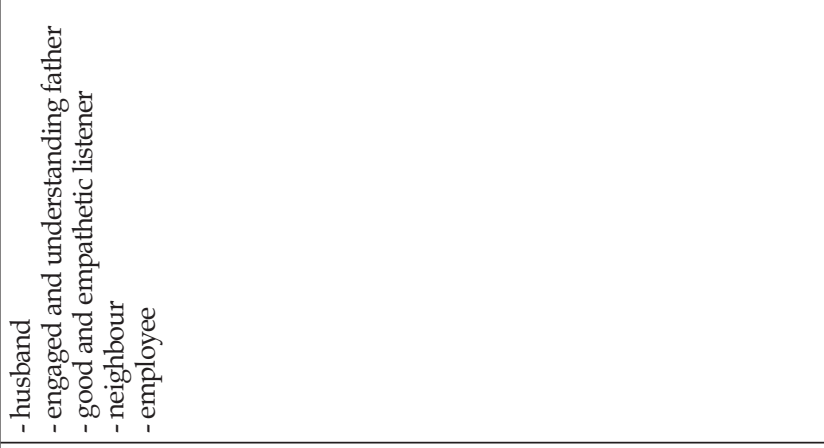 & 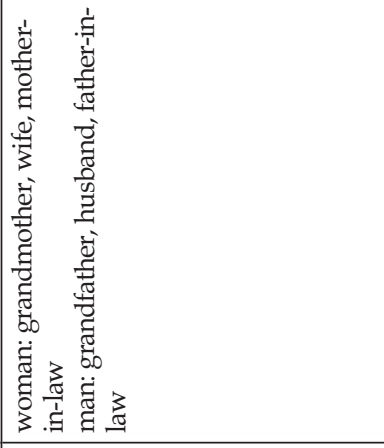 \\
\hline 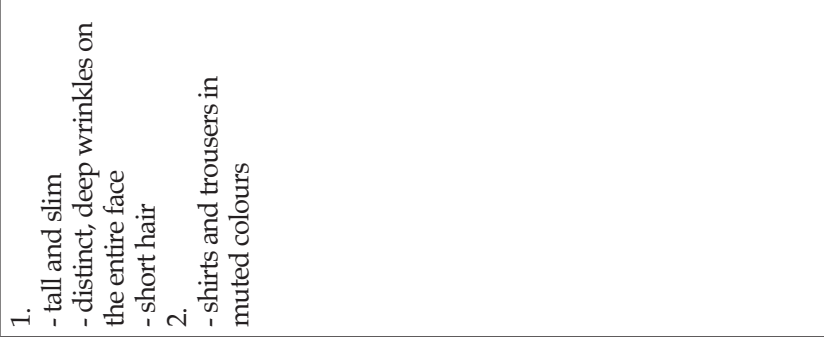 & 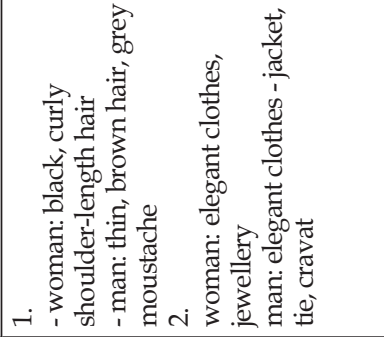 \\
\hline 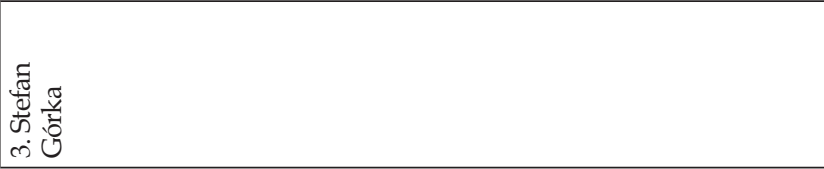 & 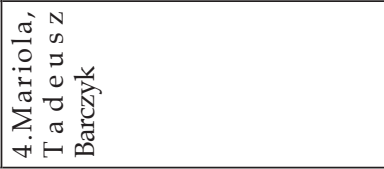 \\
\hline
\end{tabular}




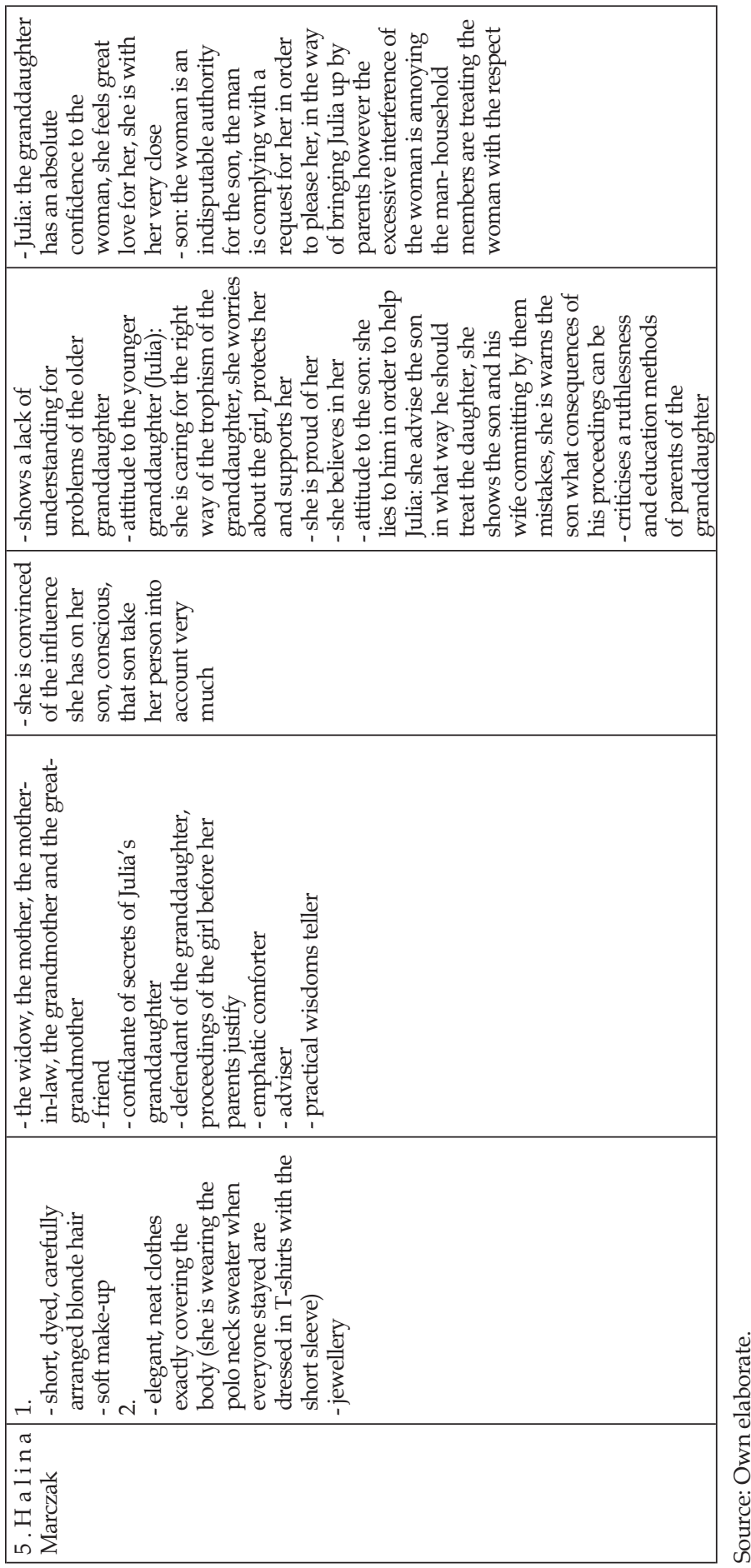




\section{SUMMARY}

Character of the elderly in pop-cultural texts is based on a large dose of conservativeness. Although television offers controversial programmes such as: game shows (e.g."The moment of truth), talk shows (e.g. "Jerry Springer") and series (e.g. "Californication" or "The Tudors"), which present direct or even vulgar erotic scenes (Ziębiński, 2010), mass media remain very careful in creating image of elderly people.

The quantitative analysis of the threads concerning old age indicates that only about $8 \%$ of the entire time was devoted to the elderly in Polish - and nearly $11 \%$ - in American series.

In described episodes the image of old age is cohesive and coherent with its stereotyped perception. Scriptwriters of both series (though, particularly of Polish series) put gigantic emphasis on showing the "third age" in the context of existing or non-existing family. So, older women are primarily grandmothers or loving and caring mothers (sometimes not being able to reconcile with an early death of their children). Men, on the other hand, as may be expected, play the roles of grandfathers, alternatively - of fathers strongly attached to their daughters. They are more often than older women portrayed in the context of the pursued occupation and potential partner relations. Only 2 out of 9 women characters in American series and none out of three in Polish series, are introduced in the context of the pursued occupation. This proportion looks totally different in the case of male forms -7 out of 9 heroes of "Desperate Housewives" and 2 out of 4 males of "Colours of happiness" are professionally active people.

It looks that the authors of analysed series transferred past opinions about characteristics and rights of the adult men and women on elderly people. It is possible to notice a greater approval of the American society of the intimacy of people in their "third age". In "Colours of happiness" subject of sexualities of both sex is being omitted. All signs of the sensitivity have an unusually subtle dimension. In "Desperate Housewives" sex is not a taboo subject. Male heroes talk directly about their preferences and needs. However, as shown in analysed series the sexual activity of men above 65 is a cause of admiration - opposite to older women, who encounter a lack of understanding or... understanding pitiable smile. Elderly ladies are treated as asexual and devoid of their own sexuality. However a great majority of ladies were described as stylish - tastefully, elegantly dressed, wearing jewellery and heavy make-up. So they are required to take care of their appearance and keep their own femininity, denying the right simultaneously using it. Moreover, they are more often portrayed in senvironment "appropriate" for grandmothers - in the kitchen, in the course of preparing meals, frequently for the entire, multigenerational family.

Old age was also shown through the prism of illness - analysed heroes are patients of hospitals, customers of pharmacies, persons in need.

"Old age as a wisdom" is also a frequent motif of old age. Older women and men perform the roles of advisors, experts of life, marriage, education, neighbourhood, friendship; they are presented as experienced and competent people., giving relevant tips and advice, making appropriate and right assessment. Particular- 
ly in Polish series, being ready to share practical wisdom and support in difficult situations co-occurs with the lack of any needs: older women and men do not talk about their own problems and desires, do not have expectations or even special requirements - on the other hand, they do not hesitate to help their children and grandchildren, unselfishly. It can be stated that older people appearing in "Colours of happiness" live in series only through and for their families.

The image of elderly people in texts of popular culture went through the real evolution - from the antiquity, when they were portrayed in the pejorative and ridiculous way (Bell, 1992 cited in: Nelson, 2003, p. 225) to contemporary times, with dominating "family" and good-natured image.

However, old age presented by the media, is still not a real old age - it appears disproportionately rarely, and is illustrated in an "improved" and "smoothed down" form, because the media still require aesthetic products. Nevertheless, some areas of old age still remain a taboo. Taking problems raised currently by mass media into consideration, we can see they are gradually changing their audience from elite groups into egalitarian (Bogunia-Borowska, 2012, p. 43), it is possible that this way of presenting old age, formerly derided, currently idealized - will finally strike a balance and approach the everyday truth.

\section{REFERENCES}

Banaszkiewicz-Zygmunt, E. (2000). Leksykon. Media. Warszawa: PWN.

Barwy szczęścia. (n.d.). Retrieved February 28, 2013, from http:/ test.barwyszczescia.tvp.pl/.

Błachnio, A. (2002). Pytanie o jakość życia w kontekście rozważań nad naturą starości. In: K. Obuchowski (Ed.). Starośći osobowość. Bydgoszcz: Wydawnictwo Akademii Bydgoskiej im. Kazimierza Wielkiego.

Bogunia-Borowska, M. (2012). Fenomen telewizji. Interpretacje socjologiczne i kulturowe. Kraków: Wydawnictwo Uniwersytetu Jagiellońskiego.

Bonikowska M., \& Leska M. (2009). Prasa, radio, telewizja w Polsce - statystyka. In: M. Bonikowska (Ed.). Media a wyzwania XXI wieku. Warszawa: Wydawnictwo TRIO.

Bugajska, B. (2012). Tożsamość człowieka w starości. Studium socjopedagogiczne. Szczecin: Wydawnictwo Naukowe Uniwersytetu Szczecińskiego.

Butler, N. R (2006). Ageism in America. Open Society Institute. Retrieved February 26, 2013, from http:/ / www.mailman.columbia.edu/sites/default/files/Ageism_in_America.pdf.

Chmielewska-Łuczak, D. (2002). Obraz człowieka starego w mediach przekazywany dzieciom w wieku przedszkolnym. In: W. Wnuk (Ed.). Ludzie starsi w trzecim tysiacleciu. Szanse - nadzieje potrzeby. Wrocław: Wydawnictwo Atla 2.

de Beauvoir, S. (2011). Starość. Warszawa: Wydawnictwo Czarna Owca.

Desperate Housewives na czele. (2006). Retrieved February 26, 2013, from http:// primetime.blox.pl/ 2006/11/Desperate-Housewives-na-czele.html

Frąckowiak, T., \& Straś-Romanowska, M. (2008). Potoczne przekonania na temat starzenia się w świetle badań psychologicznych. In: T. Kowaleski, \& P. Szukalski, P. (Eds.). Pomyślne starzenie się w perspektywie nauk społecznych i humanistycznych. Łódź: Zakład Demografii i Gerontologii Społecznej Uniwersytetu Łódzkiego.

Garncarek, E. (2005). Filmowy portret starszych kobiet. In: E. Zierkiewicz, \& A. Łysak (Eds.). Starsze kobiety w kulturze i spoteczeństwie. Wrocław: MarMar.

Godzic, W. (2004). Telewizja i jej gatunku po Wielkim Bracie. Kraków: Universitas.

Gotowe na wszystko (2004-2012) serial. (n.d.). Retrieved February 28, 2013, from http:/ / www.filmweb. $\mathrm{pl} /$ Gotowe.Na.Wszystko.

Halicki, J. (2010). Obrazy starości rysowane przeżyciami seniorów. Białystok: Wydawnictwo Uniwersytetu w Białymstoku. 
Helms, D., \& Turner, J. (1999). Rozwój człowieka. Warszawa: Wydawnictwo Szkolne i Pedagogiczne.

Janiszewska-Rain, J. (2005). Okres późnej dorosłości. Jak rozpoznać potencjał ludzi w wieku podeszłym? In: A. Brzezińska (Ed.). Psychologiczny portret człowieka. Praktyczna psychologia rozwojowa. Gdańsk: Gdańskie Wydawnictwo Psychologiczne.

Kasperek-Golimowska, E. (2008). Starość w perspektywie edukacji promującej zdrowie. In: A. Tokaj (Ed.), Starość w perspektywie studiów pedagogicznych. Leszno: Studia i Monografie Wyższej Szkoły Humanistycznej im. Króla Stanisława Leszczyńskiego.

Kępiński, A. (1983). Rytm życia. Kraków: Wydawnictwo Literackie.

Kisielewska, A. (2006). Seriale telewizyjne a kreowanie świadomości zbiorowej. In: M. Gierula (Ed.) with co-operations M. Wielopolska-Szymura, Środki masowego komunikowania a społeczeństwo. Katowice: Wydawnictwo Uniwersytetu Śląskiego.

Kołodziej, W. (2008). Bio-psycho-społeczne funkcjonowanie osób starszych a społeczne stereotypy i uprzedzenia dotyczace starzenia się i starości. In: A. Nowicka (Ed.). Wybrane problemy osób starszych. Kraków: "Impuls".

Kowgier, A. (2010). Życie intymno-emocjonalne osób starszych. Kraków: „Impuls”.

Kropińska, S., Zasadzka, E., \& Wieczorowska-Tobis, K. (2009). Dyskryminacja osób w wieku podeszłym w placówkach służby zdrowia. In: D. Talarska, \& K. Wieczorowska-Tobis (Eds.). Człowiek w wieku podesztym we wspótczesnym społeczeństwie. Poznań: Uniwersytet Medyczny im. Karola Marcinkowskiego.

Król, M. (2006). Kulturowe wzorce starzenia się na tle wybranych krajów Unii Europejskiej. In: E. Zierkiewicz, \& A. Łysak (Eds.). Trzeci wiek drugiej płci. Starsze kobiety jako podmiot aktywności społecznej i kulturowej. Wrocław: MarMar.

Leszczyńska-Rejchert, A. (2010). Człowiek starszy i jego wspomaganie - w stronę pedagogiki starości. Olsztyn: Wydawnictwo UWM.

Lewicki, A. (2011). Od House'a do Shreka. Seryjność w kulturze popularnej. Wrocław: Wydawnictwo Uniwersytetu Wrocławskiego.

Łaciak B. (2006). Polskie seriale obyczajowe jako element dyskursu o problemach społecznych. Societas/ Communitas 2(2).

Łysak, A. (2005). (Nie)obecność starszych kobiet w prasie młodzieżowej. In: E. Zierkiewicz, \& A. Łysak (Eds.). Starsze kobiety w kulturze i społeczeństwie. Wrocław: MarMar.

Łyszkowska, E., \& Sojka, A. (2005). Wizerunek starszej kobiety w telewizji na przykładzie reklamy i analizy zachowań telewizyjnych. In: E. Zierkiewicz, \& A. Łysak (Eds.). Starsze kobiety w kulturze i społeczeństwie. Wrocław: MarMar.

Mazurek-Lipka, O. (2012). Popkulturowa tożsamość współczesnego widza. Przyczyny, dla których uwielbiamy oglądać CSI i inne filmy o profesjonalistach. In: A. Cybal-Michalska, \& P. Wierzba (Eds.). Dyskursy kultury popularnej w społeczeństwie wspótczesnym. Kraków: „Impuls”.

Mielczarek, A. (2010). Człowiek stary w domu pomocy spotecznej. Z perspektywy polityki społecznej i pracy socjalnej. Torun: Wydawnictwo Edukacyjne Akapit.

Mituła E. (2006). Bohaterki serialu „M jak miłość” w kontekście gerontologicznym. In: E. Zierkiewicz, \& A. Łysak (Eds.). Trzeci wiek drugiej ptci. Wrocław: MarMar

Najpopularniejsze w TV. (2013). Retrieved February 28, 2013, from http://www.swiatseriali.pl/ ogladalnosc,date,2013-02-25.

Nelson, T. D. (2003). Psychologia uprzedzeń. Gdańsk: GWP.

Nowicka, A. (2008). Starość jako faza życia człowieka. In: A. Nowicka (Ed.). Wybrane problemy osób starszych. Kraków: „Impuls”.

Oglądalność seriali w USA na jesień 26gru10. (2010). Retrieved February 26, 2013, from http:/ / nowepogloski.wordpress.com/2010/12/26/ogladalnosc-seriali-w-usa-na-jesien/.

Pater, A. (2002). Telenowela jako naturalne środowisko współczesnego Kopciuszka. In: W. Jakubowski, \& E. Zierkiewicz (Eds.). Edukacyjne konteksty kultury popularnej. Kraków: „Impuls”.

Pawlina, A. (2011). Stereotypowe wizerunki starości w wybranych przekazach kulturowych. In: M. Malec (Ed.). Edukacyjne, kulturowe i społeczne konteksty starości. Wrocław: Oficyna Wydawnicza ATUT- Wrocławskie Wydawnictwo Oświatowe.

Pawłowska, R., \& Jundziłł, E. (2006). Pedagogika człowieka samotnego. Gdańsk: Wydawnictwo Gdańskiej Szkoły Humanistycznej.

Pikuła, N. (2011). Gerontologia dla pracowników socjalnych. Etos starości w aspekcie społecznym. Kraków: Wydawnictwo WAM. 
Podgórski, M. (2009). Pomiędzy tym, co do pomyślenia i tym, co nie do pomyślenia. In: H. Jakubowska, A. Raciniewska, \& Ł. Rogowski (Eds.). Patrząc na starość. Poznań: Wydawnictwo Naukowe UAM.

Podsiadła, E. (2009). Starość - nowe tabu. In: H. Jakubowska, A. Raciniewska, \& Ł. Rogowski (Eds.). Patrząc na starość. Poznań: Wydawnictwo Naukowe UAM.

Ratkowska, L. (2006). Starsze kobiety w „Przyjaciółce” z 1949 roku. In: E. Zierkiewicz, \& A. Łysak (Eds.). Trzeci wiek drugiej ptci. Starsze kobiety jako podmiot aktywności społecznej i kulturowej. Wrocław: MarMar.

Robbins, J. C. (2006). „Starsi Amerykanie” a choroba Alzheimera. Biopolityka, podmiotowość i obywatelstwo. In: E. Zierkiewicz, \& A. Łysak (Eds.). Trzeci wiek drugiej ptci. Starsze kobiety jako podmiot aktywności społecznej i kulturowej. Wrocław: MarMar.

SERIALE we WRZEŚNIU 2012 - WYNIKI OGLĄDALNOŚCI seriali - M jak MIŁOŚĆ ponad 7 MLN widzów. (2012). Retrieved February 28, 2013, from http://superseriale.se.pl/seriale/seriale-we-wrzesniu2012-wyniki-ogladalnosci-seriali-m-jak-milosc-ponad-7-mln-widzow_282772.html.

Shrestha, L. B., \& Heisler, I. J. (2011). The Changing Demographic Profile of the United States. Congressional Research Service. Retrieved February 26, 2013, from http://www.fas.org/sgp/crs/misc/ RL32701.pdf.

Skrzypczak, J. (1998). Media tom III. Suplement do Wielkiej Ilustrowanej Encyklopedii powszechnej wydawnictwa Gutenberga. Poznań: Wydawnictwo Kurpisz.

Skrzypczak, J. (1995). Popularna encyklopedia Mass Mediów. Poznań: Wydawnictwo Kurpisz.

Sobczak, I. (2011). Bilans ludności. In: Z. Strzelecki (Ed.). Sytuacja demograficzna Polski. Raport 2011-2012. Rządowa Rada Ludnościowa: Warszawa.

Sosnowski T. (2007). Modele ojcowskie w serialu telewizyjnym „M jak Miłość” - kontekst pedagogiczny. In: B. Siemieniecki (Ed.). Manipulacja media edukacja. Toruń: Wydawnictwo Adam Marszałek

Stelcer, B. (2009). Niektóre modele starzenia się w świetle psychologii rozwojowej. In: D. Talarska, \& K. Wieczorowska-Tobis (Eds.). Człowiek w wieku podesztym we wspótczesnym społeczeństwie. Poznań: Uniwersytet Medyczny im. Karola Marcinkowskiego.

Steuden, S. (2011). Psychologia starzenia się i starości. Warszawa: Wydawnictwo Naukowe PWN.

Straś-Romanowska, M. (2000). Późna dorosłość. Wiek starzenia się. In: B. Harwas-Napierała, \& J. Trempała (Eds.). Psychologia rozwoju człowieka. Charakterystyka okresów życia człowieka. Warszawa: Wydawnictwo Naukowe PWN.

Stuart-Hamilton, I. (2000). Psychologia starzenia się. Poznań: Zysk i S-ka Wydawnictwo.

Szatur-Jaworska, B., Błędowski, P., \& Dzięgielewska, M. (2006). Podstawy gerontologii społecznej. Warszawa: Oficyna Wydawnicza ASPRA.

Taylor, L., \& Willis, A. (2006). Medioznastwo. Teksty, instytucje i odbiorcy. Kraków: Wydawnictwo Uniwersytetu Jagiellońskiego.

The Most Watched TV Shows, Season 2011-2012 [US Broadcast Nets.]. (2012). Retrieved February 26, 2013, from http://muhsadam.wordpress.com/2012/06/01/ the-most-watched-tv-shows-2011-12-season-us-broadcast-nets/.

Wawrzyn, M. (2012). Jakie seriale najchętniej oglądaja Polacy? Retrieved February 28, 2013, from http:// www.serialowa.pl/28706/jakie-seriale-najchetniej-teraz-ogladaja-polacy/.

Wysocka, E. (2005). Babcia czy Megiera? Wizerunki starych kobiet w polskich serialach obyczajowych. In: E. Zierkiewicz, \& A. Łysak (Eds.). Starsze kobiety w kulturze i społeczeństwie. Wrocław: MarMar.

Vigué, J., \& Villalobos, G. (2007). Encyklopedia zdrowia dojrzatość. Warszawa: Bellona.

Zierkiewicz, E., \& Anioł, J. (2012). Media jako instrument polityki społecznej państwa? Serial telewizyjny w służbie edukacji dorosłych. Analiza "Głębokiej wody”. In: W. Jakubowski (Ed.). Kultura jako przestrzeń edukacyjna. Wspótczesne obszary uczenia się osób dorostych. Kraków: „Impuls”.

Zierkiewicz, E. (2005). Na co komu stara kobieta w kolorowym czasopiśmie? Strategie wykluczania i strategie (przymuszonego?) uobecniania starszych kobiet w prasie kobiecej. In: E. Zierkiewicz, \& A. Łysak (Eds.). Starsze kobiety w kulturze i społeczeństwie. Wrocław: MarMar.

Ziębiński R. (2010). „Californication”: seks, narkotyki i Jezus Chrystus, Retrieved July 24, 2013, from http:// kultura.newsweek.pl/-californication---seks--narkotyki-i-jezus-chrystus,62462,1,1.html 